Jurnal Ilmu Sosial dan Pendidikan (JISIP)

Vol. 6, No. 1 Januari 2022

e-ISSN : 2656-6753, p-ISSN: 2598-9944

DOI: 10.36312/jisip.v6i1.2730/http://ejournal.mandalanursa.org/index.php/JISIP/index

\title{
Akhlak Siswa terhadap Guru Pada Pendekatan Normatif di Dalam Al-Qur'an dan Hadis
}

\author{
Khoirunisa $^{1}$, Sutrisno ${ }^{2}$ \\ ${ }^{1,2}$ Universitas Islam Negeri Sunan Kalijaga
}

\begin{tabular}{l}
\hline Article Info \\
\hline Article history: \\
Received 20 Desember 2021 \\
Publish 04 Januari 2022 \\
\end{tabular}

Keywords:

Morals of students

Teachers

Normative

Al-Qur'an

Hadith

\begin{abstract}
The normative approach is to understand religion using the framework of God's knowledge, the view of the main and original teachings from God in which there is no human reasoning. The purpose of this study was to see the morals of students towards teachers according to the Qur'an and Hadith. This research method is descriptive qualitative. The method in this study is a library method, the data collected are books and previous studies that are relevant for this research. In the data source section, there are verses from the Qur'an and hadith that contain students' morals towards teachers, reading books that refer to research theory, and several related previous studies. Data collection techniques used reading and notetaking techniques. The data analysis technique in this study is content analysis using a normative approach to the text in the verses of the Qur'an and Hadith and in the form of articles from the journal Sinta 2-5 as many as 4 articles containing moral habits based on a normative approach. Normative matters regarding student morals in the school community and family environment do need to be emphasized according to the verses of the Qur'an and hadith, this is able to form noble character in children from an early age.
\end{abstract}

\section{Info Artikel}

Article history:

Diterima 20 Desember 2021

Publis 04 Januari 2022

\begin{tabular}{l}
\hline ABSTRAK \\
Pendekatan normatif adalah memahami agama dengan menggunakan kerangka Ilmu \\
tentang tuhan, pandangan dari pengajaran pokok serta orisinil berasal tuhan \\
didalamnya belum terdapat penalaran pemikiran manusia. Tujuan penelitian ini \\
untuk melihat akhlak siswa terhadap guru sesuai al qur'an dan hadis. Metode \\
penelitian ini ialah deskriptif kualitatif. Metode dalam penelitian ini merupakan \\
metode kepustakaan, data yang dikumpul merupakan buku-buku dan penelitian \\
terdahulu yang relevan, untuk penelitian ini. Pada bagian sumber datanya \\
merupakan ayat-ayat al-Qur'an dan hadis yang memuat akhlak siswa terhadap guru, \\
buku-buku bacaan yang mengacu pada teori penelitian, dan beberapa penelitian \\
sebelumnya yang terkait. Teknik pengumpulan data menggunakan teknik membaca \\
serta mencatat. Teknik analisis data dalam penelitian ini ialah analisis isi \\
menggunakan pendekatan normatif terhadap teks yang ada di ayat-ayat Alquran dan \\
hadis serta berupa artikel dari jurnal Sinta 2-5 sebanyak 4 artikel berisi pebiasaan \\
akhlak berdasarkan pedekatan normatif, hasil dari analisis penelitian ini \\
menjelaskan bahwa pendekatan normatif perihal akhlak siswa pada lingkungan \\
masyarakat sekolah juga keluarga memang perlu ditegaskan sesuai ayat-ayat Al- \\
Qur'an serta hadis, ini mampu membentuk akhlak yang mulia pada anak semenjak \\
dini. \\
\hline This is an open access article under the Lisensi Creative Commons Atribusi- \\
\hline BerbagiSerupa 4.0 Internasional \\
\hline (i) (2)
\end{tabular}

Corresponding Author:

Khoirunisa,

UIN Sunan Kalijaga

Email: 21204081011@student.uin-suka.ac.id 


\section{PENDAHULUAN}

Islam sudah memutuskan aturan dalam kehidupan umat-nya, untuk itu tak heran saat Nabi Muhammad sendiri menyatakan sebuah tujuan menjadi rasul yaitu buat membentuk akhlak manusia yang lebih baik. (Salsabila \& Firdaus, 2018) dalam sejarah manusia, persoalan akhlak ini terus menjadi pokok permasalahan, di sebakan tingkah laku sebagai manusia secara tak langsung maupun secara langsung serta semua itu masih sebagai perbandingan buat mengetahui serta penilaian perbuatan maupun perilaku mereka. Akhlak menduduki tempat penting dalam kehidupan kita sebagai bagian dari masyarakat maupun seabagi bangsa, karena berkembangnya prilaku baik manusia maka akan sejalan juga pada akhlaknya. Bila akhlaknya bagus, maka lahir batinnya juga akanmengikuti namun apabila buruk, maka akan buruk juga lahir batinya, sebagai makhluk yang mulia, dengan istilahnya akhlak yaitu sifat-sifat yang sudah dibawa dari seseorang dilahirkan yang tertanam pada jiwanya serta selalu terdapat padanya Al-Qur'an menandakan, yaitu akhlak itu jelek maupun bagusnya akan mencerminkan diri seseorang sesuai dengan pembinaan serta pembentukannya. (Firdaus, 2017)

Persoalan akhlak ini merupakan pokok utama pada ajaran Islam, ini merupakan hal yang sangatlah penting, ini juga merupakan tugas Nabi Muhammad Saw. Yaitu memperbaiki akhlak manusia, agar manusia mempunyai sikap baik untuk mengarungi kehidupan. Namun Masih banyak masyarakat yang mengalami krisis akhlak, terlihat dari banyak nya permaslahan yang terjadi atas perbuatan yang dilakukan masyarakat termuat pada media cetak ataupun media elektronik. Akhlak merupakan sebuah kekuatan dari diri sendiri yang berkombinasi antara kecenderungan pada sisi yang baik serta sisi yang buruk. (Salsabila and Firdaus). Perkembangan akhlak pada dunia pendidikan saat ini khusus pada bentuk moral atau norma-norma yang dipunyai maupun siswa yang ada di bidang pendidikan sangat lah minim untuk mencontohkan tentang tujuan pendidikan Nasional. Mengingat pendindikan mempunyai tujuan yaitu memanusiakan manusia (Depdiknas, 2003:43) oleh sebab itu sudah sangat jelas mengatakan bahwa pendidikan sangat mulia.

Pada penelitian literatur review ini terdapat sebuah konflik akhlak siswa pada guru masih tak mencerminkan norma-norma yang telah ada di dalam al-quraan serta hadis, sementara di dalam alquraan serta hadis telah menyebutkan ayat yang membahas tentang berakhlak maupun beradab pada sesama, bisa kita lihat contoh pada zaman sekarang banyaknya kasus yang membahas peserta didik yang mebentak, berbicara kotor, bahkan hingga menganiyaya guru, dalam penelitian ini sangat penting bagi kita seseorang tenaga pendidik selain orang tua guru juga berperan penting pada pembentukan akhlak peserta didik, ini yang menjadi sebab mengapa pentingnya mengenal ajaran alquraan sebagai sumber yang telah jelas, dalam pebentukan akhlak peserta didik yang terjadinya ketidakcocokan maupun kesenjagan dengan kenyataan. sesuai latar belakang masalah diatas permasalahan dalam peneltian ini adalah mengapa kebiasaan dalam berakhlak kepada guru belum menjadi kebiasaan pada siswa dan masih terjadinya seorang siswa tidak mencerminkan normanorma yang sudah terdapat di dalam al-quraan dan hadis.

Dari permasalahan diatas penelitian ini bertujuan untuk menemukan sebab-sebab mengapa dalam berakhlak yang mulia belum menjadi kebiasaan serta menemukan cara untuk membentuk akhlak siswa sesuai dengan ajaran islam dalam pendekatan normatif yaitu norma- norma berdasarkan sumber al-quraan maupun hadis, berdasarkan analisis dari artikel jurnal penelitian terdahulu yang membahas akhlak siswa terhadap guru.

Untuk menjawab permasalahan-permasalahan yang berkaitan dengan agama maupun nomanorma dalam kehidupan ini merupakan pendekatan dalam pengkajin islam yang bisa diselesaikan menggunakan pendekatan normatif. Pendekatan normatif yaitu berpegang teguh menggunakan norma serta perinsip yang sudah ditetapkan, menurut Abudin Nata, pendekatan normatif merupakan bagian pemahaman serta memperkenalkan bentuk Islam dengan melihat Islam dari bentuk ajarannya yang pokok dan asli berasal tuhan di dalamnya belum ada pemikiran manusia.(Shaifudin) Pendekatan normatif mempunyai jangkauan meluas. karena semua pendekatan yang dipergunakan 
pakar pakar hukum Islam (Fuqaha), pakar tafsir (mufassirin) usul fiqih (Ushuliyah), yang selalu mencari sudut pandang sah formal serta ajaran Islam dari Sumbernya ialah merupakan pendekatan normatif.

Berdasarkan Bermi wibawati, dari artikel jurnal dengan judul "Internalisasi Nilai-Nilai agama Islam untuk membentuk perilaku serta sikap peserta didik Sekolah Dasar Islam Terpadu AlMukminun Ngrambe Ngawi" mengungkapkan bahwa dari hasil penelitian Pendekatan untuk menanamkan nilai-nilai agama Islam pada peserta didik dilaksanakan dengan tahap pendekatan melalui beberapa tahap yaitu: pertama dengan cara mengajak dan pembiasaan Sedang aspek nilai nilai agama Islam yang ditumbuhkan pada SDIT Al- Mukminun Ngrambe mencakup: aspek kecintaan pada Al-Qur'an; sudut pandang ibadah sholat serta zikir terhadap Allah; pembiasaan untuk membaca doa jika hendak melaksanakan aktivitas dan mengucapkan syukur, bulan ramadhan ikut berpuasa, mengenakan pakaian islami, memberi salam, Bila berjumpa teman, orang tua, ketika hendak memasuki rumah, mencium tangan ayah dan ibu saat hendak pergi ke sekolah, beradab sopan maupun santun terhadap guru, orang tua serta tetangga, menolong sesama orang yan membutuhkan bantuan, memberi sedekah, berkata jujur, disiplin mandiri, bisa bertanggung jawab serta anjuran untuk menjaga maupun memelihara kelestarian lingkungan merupakan bentuk iman dan taqwa pada Allah. (Bermi)

Dari penelitian Abdul Jabar Idhaudin, Akhmad Alim, \& Abdul Hayyie Al Kattani dengan judul Penerapan Model Pendidikan Akhlak Syaikh Utsaimin Di Sdit Al-Hidayah Bogor, Pada hasil penelitian tentang Penerapan model Pendidikan Akhlak Syaikh Utsaimin pada SDIT Al-Hidayah Bogor bisa disimpulkan bahwa: pertama al-quraan, hadis serta ijtihad ulama sebagai landasan untuk internalisasi melalui visi mis sekolah, kedua yaitu bertujuan mewujudkan akhlak yang mulia terhadap peserta didik yang mampu menciptakan budaya islami bagi unsur pendidikannya. Ketiga yaitu kurikulum yang dimensinya pada mata pelajaran dan program sekolah yang berdasarkan untuk penumbuhan nilai nilai akhlak dan yang keempat yaitu pada metode penumbuhan nilai-nilai akhlak dalam al-quraan serta hadis, menyebutkan bahwa keutamaan akhlak mulia serta ancaman akhlak tercela, mewujudkan lingkungan islami melalui membiasakan teladan terhadap akhlak Rasullullah Saw, metode kisah, pembiasaan, targhib, keteladanan serta tarhib, tafakur serta tadabbur, dan pelaksanaan kemitraan sekolah menggunakan internal masyarakat sekolah dan kemitraan sekolah dengan pihak keluarga serta masyarakat untuk mengawasi akhlak siswa, kelima mengevaluasi bentuk dari supervisi siswalewat observasi, lalu dicatat di pada buku jurnal lalu direkap untuk laporan akibat belajar dengan latihan atas faktor keberhasilan maupun penghambatnya, sehingg peserta didik dapat memperbaiki ketertinggalan akademik dan ketidak baikan perilaku dengan penguatanyang intensip oleh pihak sekolah. (Idhaudin et al.) dari Mudir, jurnal menggunakan judul "penerapan pendekatan saintifik dan normatif dalam pembelajaran aqidah akhlak di madrasah ibtidaiyah" hasil dari penelitian mengungkapkan bahwa penelitian tersebut menunjukkan bahwa aplikasi pembelajaran menggunakan pendekatan saintifik, normatif, dan praktik,

Berdasarkan Mudir, jurnal dengan judul (penerapan pendekatan saintifik serta normatif pada pembelajaran aqidah akhlak di madrasah ibtidaiyah) hasil dari peneliitian menyebutkan bahwa penelitian tersebutmenjelaskan yaitu tentang pelaksanaan pembelajaran menggunakan pendekatan normatif, saintifik, dan praktik.

1. Pendekatan saintifik adalah yang ambil untuk pelajaran Aqidah Akhlak menggunakan materi yang sering bisa dan lebih praktis dalam penjelasan bisa rasional dengan memakai tahapan lima M, adalah: mengamati, menanya, mengumpulkan, mencoba, menalar, dan tahap mengkomunikasikan. pengajar Aqidah Akhlak yang lebih tahu materi yang mampu dan praktis dijelaskan.

2. Pendekatan normatif. Pendekatan normatif bisa dilihat menjadi sebalik dari saintifik bisa ditinjau menjadi pendekatan yang bisa melengkapi. Pendekatan normatif diimplementasikan pada 
pembelajaran Aqidah Akhlak yang materinya mengharuskan bisa dijelaskan dengan normatif, dogmatis, apa adanya, atau tekstual.

3. Pendekatan Praktik. adalah pembelajaran yang mengharuskan untuk bagian pengamalan materi Aqidah Akhlak dalam lingkungan hidup sehari-hari diawali pada lingkungan sekolah. Harapan ini, mebiasakan pengamalan ini akan berlanjut pada kehidupan di dalam kehidupan dalam keluarga maupun pada kehidupan bermasyarakat.

Dapat peneliti simpulkan bahwa hasil dari tiga pendekatan ini dalam membentuk akhlak siswa, tergabungnya penilaian tiga bagian ini bisa menjelaskan kapasitas, gaya, dan perolehan belajar siswa maupun bisa mendapatkan dampak instruksional serta pengiring dari pembelajaran. (Mudir). Penelitian Ani Nur Aeni jurnal menggunakan judul, Pendidikan Karakter bagi peserta didik Sekolah Dasar dalam Perspektif Islam pada penelitian ini mengungkapkan bahwa Undang undang No 20 Tahun 2003. dalam Islam pendidikan karakter mempunyai arti sendiri, pendidikan akhlak, Para filosof muslim merumuskan tentang tujuan dari pendidikan bermuara pada akhlak. peserta didik Sekolah Dasar sangat penting menerima pendidikan karakter mengingat di usia ini peserta didik wajib telah mempunyai perilaku bertanggung jawab, simpati serta mandiri yang sinkron terhadap tahap perkembangan moral mereka. Landasan pendidikan karakter dalam islam bersumberkan pada Al-Quraan serta Hadis. (Ani)

pada jurnal ini juga menjelaskan bahwa perlunya dibentuk pendidikan karakter atau dalam pandangan islam adalah akhlak di usia dini, dengan bersumberkan dari al-quraan dan hadis.

Jurnal oleh Ibrahim Bafadhol pada jurnal ini mengemukakan yaitu Akhlak Islami mempunyai beberapa keistimewaan serta terutama karakteristik sebgai pembeda asal dari sistem akhlak lainnya, memiliki ciri islami yaitu: (a) Rabbaniyah yaitu pemahaman kepada sang pencipta (tuhan), (b) insan yang bersifat manusiawi (c) islam sebagai agama yang sempurna (menyeluruh serta merangkul seluruh kehidupan), (d) Wasathiyah (perilaku pertengahan). Hal yang diharuskan di dalam islam adalah pendidikan akhlak wajib ditumbuhkan sejak masa anak-anak ini merupakan masa yang paling cocok buat menanamkan norma yang baik. (Bafadhol),

Dari penjelasan diatas peneliti menarik kesimpulan bahwa akhlak yang baik wajib dimulai sejak dini dengan membiasakan siswa sehingga terbentuknya akhlak yang baik dimasa depan. Berdasarkan hasil beberapa penelitian terdahulu penulis menyimpulkan bahwa dengan penerapan nila-nilai akhlak sesuai kaidah al-quraan serta hadis pada kehidupan sehari-hari pada lingkungan sekolah berawal dari masa anak berusia dini ini akan membentuk sebuah pembiasaan yan nantinya memiliki tujuan agar terwujudnya siswa yang berakhlak mulia, serta membentuk budaya islami pada unsur pendidikannya.

\section{KAJIAN TEORI}

Pendekatan normatif pada pelajaran islam merupakan suatu tanggapan seseorang untuk menemukan, memahami, dan mengungkapkan hal keilmuan keislaman. Pengetian tentang Islam ini mendapatkan evaluasi atas seseuatu sesuai norma (ayat Al-quran serta hadis) dengan tekstual yang tidak ada manusia yang ikut campur. Pendekatan normatif memiliki ranah yang sifatnya pada iman, tanpa melakukan pengeritikan. Pendekatan ini menggunakan menyeluruh dalam ajaran Islam (Alquran dan Hadits) sebagai sebuah kebenaran yang nyata, dan bisa diterima dan tidak diganggu gugat. Pandangan Islam secara normatif memiliki sifat menjadikan islam sebgai objek pelajaran yang diyakinkan sebagai sesuatu yang suci sumbernya dari tuhan yang mempunyai kebenaran yang mutlak, sempurna serta menyeluruh sebagai contoh yaitu turunnya Alquran yang artinya aspek normatif Islam kmemiliki tempat sempurna, sehingga kebenaran yang terdapat di dalam Al-quran adalah kebenaran pasti. ('Adzim and Vrikati)

berdasarkan Abuddin Nata, studi Islam dengan pendekatan normatif yaitu sebuah pendekatan yang menganggap agama dari segi ajarannya berasal dalam bentuk ajarannya pokok dan asli dari sang pencipta, agama memiliki sifat mengikat pada para pemeluknya, maka ajaran-ajaran moral agama memiliki besar pengaruh terhadap ajaran-ajaran moral yang dihasilkan falsafah dan 
pemikiran manusia dengan begitu inilah yang membentuk tata cara akhlak yang diajarkan agama memiliki dampak besar dalam membimbing manusia yang berakhlak mulia. (Mudir)

dari Charles J, Pendekatan normatif juga merupakan, pengkajian agama lebih berpengaruh oleh motivasi serta kepentingan sebuah agama tertentu. Prinsip dasar pendekatan ini melihat Islam atau kepercayaan sesuai teks yang telah tertulis pada kitab suci masing-masing yang bercorak literal, tekstual serta pasti. (Nur)

\section{Pendidikan Akhlak}

Islam adalah agama yang sempurna, pada ajarannya agama Islam memiliki landasan pemikiran, juga terhadap pendidikan akhlak. tidak dapat diragukan lagi bahwa pendidikan akhlak di agama Islam bersumber berasal Al-Qur'an dan hadis. Al-Qur'an sendiri menjadi landasan utama pada agama Islam dan menjadi panduan dan sudah memberikan petunjuk ke jalan kebenaran, menunjukkan kita untuk mencapai kebahagiaan di dunia dan akhirat. Al-Ghazali mengemukakan tentang akhlak, yaitu sifat atau keadaan berasal sikap yang memang ada dan teresap pada jiwa, ini menumbuhkan perbuatan-perbuatan yang lumrah dan mudah, tidak memerlukan pikiran dan pertimbangan. Dari pengertian diatas, hakikat akhlak dari al-ghazali meski meliputi 2 syarat sebgai berikut: 1. Perbuatan meski konsisten yang dikerjakan berulang-ulang dengan bentuk yang sama. sehingga bisa menjadi kebiasaan. 2. Perbuatan yang harus berkepanjangan meski tumbuh dengan mudah sebagai bentuk refleksif dari jiwa tanpa pertimbangan maupun pemikiran, ini bukan tidak ada tekana-tekanan, paksaan-paksaan dari orang lain, atau dampak-dampak dan bujukan-bujukanbujukan yang indah dan sebagainya. (Gustini).

Al-Ghazali megemukakan arti akhlak yang baik, yaitu salah satunya, hati tidak kotor dan suci berdasarkan Al-Quraan yaitu:

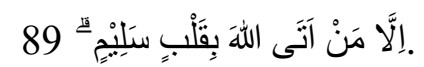

Artinya: kecuali orang yang menghadap Allah dengan hati yang suci. (QS 42 Al-Syua'ara:

Berdasarkan deskripsi diatas, bisa dianalisis yaitu ada hubungan yang relevan antara akhlak yang baik yang telah Al-Ghazali berkenan pada upaya seseorang agar membahagiakan dirinya. Selain itu ayat yang lain juga mengatakan bahwa pentingnya akhlak terdapat dalam surat Ali Imran ayat 104:

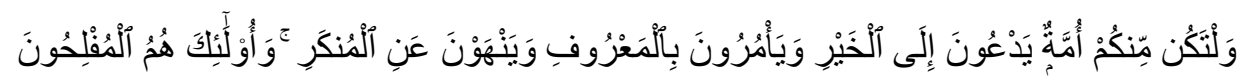

Artinya: Dan hendaklah ada di antara kamu segolongan umat yang menyeru kepada kebajikan, menyuruh kepada yang makruf dan mencegah dari yang munkar; merekalah orangorang yang beruntung. (Ali Imran ayat: 104)

pada ayat tersebut Allah SWT menganjurkan kita sebagai hamba agar bisa membimbing mengajar mendidik maupun memberi nasehat sesama manusia baik dalam melaksanakan kebaikan serta menjauhi keburukan. Dengan begitu Allah sudah memberikan dasar yang jelas tetang pendidikan akhlak adalah akhlak ini juga merupakan suatu usaha agar mengarahkan serta membimbing seseorang supaya berbudi pekerti yang baik dan berakhlaqul karimah.

\section{Tujuan Pendidikan Akhlak}

Dari Mahmud (2003: 121) mengungkapkan tujuan pendidikan akhlak mencakup aspek yaitu (1) membimbing seseorang agar mempunyai iman yang baik agar bisa berbuat kebajikan, (2) membentuk seseorang untuk selalu taat tentang halal dan haram, (3) mempersiapkan manusia yang sholeh mempunyai hubungan sosial bagus, (4) mempersiapkan manusia yang sholeh yang menjaga persaudaraan islami (5) mempersiapkan orang yang sholeh yang siap berdakwah, (6) mempersiapkan mukmin sholehh yang bangga atas dirinya karena beragama islam kepada hamba Allah Swt, (7) membimbing orang sholeh agar selalu berkorban dalam memperjuangkan agama Allah. 
Tujuan pendidikan akhlak di sekolah apada dasarnya untuk membentuk hubungan terhadap hidup manusia antara aspek dunia serta akhirat dengan seimbang dengan akhlak yang baik dimulai sejak masa anak-anak sampai akhir hayat sebagai bentuk mentaati perintah Allah Swt. Membimbing manusia agar bisa memahami serta melakukan hakikat tujuan penciptaanya, merupakan bagian utama dari tujuan pendidikan akhlak yang diorientasikan buat beribadah kepada Allah Swt. (Idhaudin et al.)

\section{Ruang Lingkup Pendidikan Akhlak}

Orang yang baik seringkali dianggap orang yang mempunyai akhlak, sedangkan orang yang tak mencerminkan perlakuan baik dianggap orang yang tidak berakhlak. secara istilah, akhlak artinya sistem nilai yg mengatur bentuk perilaku maupun tindakan manusia di dunia. Sistem nilai yang dimaksud adalah ajaran Islam, dengan Al-Quraan serta Hadis sebagai asal nilai dan ijtihad merupakan metode berfikir Islami, dikarenakan melalui 2 sumber tersebut manusia bisa mengerti tentang tingkah laku yang baik dan perilaku yang jelek. (Firdaus) Berikut aspek ruang lingkup pendidikan akhlah:

\section{a. Akhlaq pada Allah SWT}

Umat islam mempunyai akidah yang kuat serta benar memiliki kewajiban untuk menjaga keinginannya dengan meluruskan ibadah serta ketaatan sesuai tauhid, taat terhadap perintah serta menjauhi larangan serta beramal sholeh. Nilai karakter dalam kurikulum salah satunya merupakan karakter religius. Nilai religius artinya tingkah laku yang taat dalam menjalankan kepercayaan, akur serta kuat atas toleransi terhadap agama lain. seorang bisa dikatakan beriman saat selalu mendekatkan diri kepada Allah SWT, karakter religius bisa disimpulkan sebuah pendekatan seseorang pada Allah SWT, dengan dasar tingkah laku dan sikap sebagai wujud pendekatan kepada Allah SWT. (Ahmad, AFghor Fahruddin)

\section{b. Akhlak kepada diri sendiri}

Agama Islam mengajarkan pada kaum muslim untuk berakhlak yang mulia kepada dirinya sendiri. manusia yang sudah diciptakan oleh Allah SWT serta pada keadaan fitriahnya memiliki kewajiban menjaganya dengan cara memelihara kesucian lahir dan batin, berikut ayat Al-Quraan yang menjelaskan tentang akhlak kepada diri kita sendiri terdapat pada surah At-Taubah: 108

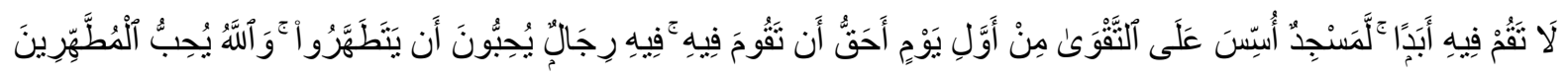

Artinya: Jangan lah kamu sholat dalam masjid itu selama-lamanya. Sesungguhnya masjid yang didirikan atas dasar takwa (mesjid Quba), sejak hari sholat di dalamnya. Di dalamnya ada orang-orang yang ingin membersihkan diri. Dan Allah menyukai orangorang yang bersih. (QS At-taubah ayat 108

\section{c. Akhlak Terhadap Keluarga}

Akhlak kepada keluarga ini dilasanakan dengan cara berbuat baik dan berbakti kepada ayah dan ibu sebagai orang tua, berteman dengan baik, memberi makan serta kebutuhan keluarga sebaik mungkin, merawat serta menjadi anak yang sholeh maupun sholeha.

\section{d. Akhlak kepada tetangga}

Bersikap baik terhadap tetangga merupakan hal yang penting, karena tetangga merupakan sahabat yang paling dekat. Nabi Muhammad SAW bersabda serta menjelaskan bahwa 
Tidak henti-hentinya jibril menyuruhku untuk berbuat baik kepada tetangga, hingga aku merasa tetangga sudah seperti ahli waris (HR Bukhori)

\section{e. Akhlak dalam kepemimpinan}

Kita sebagai manusia wajib siap menjadi pemimpin serta dipimpin Jika kita sebagai seseorang pemimpin maka kita mempunyai kewajiban untuk mempunyai akhlak yang baik, karena sebagai pemimpin kita harus memberikan contoh teladan yang pantas ditiru oleh banyak masyarakat, jika kita sebagai orang yang dipimpin meski maka taat dan patuh kepada pemimpin kita selama pemimpin kita tidak berbuat dzolim

\section{f. Akhlak kepada lingkungan}

Lingkungan yang yang diartikan yaitu yang merupakan segala sesuatu di sekitar manusia seperti binatang, tumbuhan maupun benda mati. Akhlak yang dikembangkan merupakan cerminan dari tugas manusia yang menjadi pemimpin dimuka bumi ini untuk menjaga agar setiap tahap pertumbuhan alam bisa terus berjalan tepat terhadap fungsi kreasi-Nya. (Ahmad, AFghor Fahruddin) Berikut ayat al-quraan surah Al-An'am ayat: 38

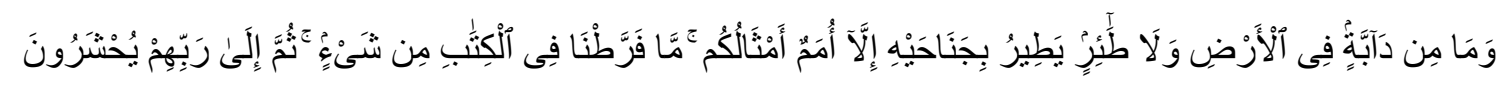

Artinya: Dan tiadalah binatang-binatang yang ada di bumi dan burung-burung yang terbang dengan kedua sayapnya, melainkan umat-umat (juga) seperti kamu. Tiadalah Kami alpakan sesuatu pun di dalam Al Kitab, kemudian kepada Tuhanlah mereka dihimpunkan. (QS. Al-An'am ayat 38)

Berikut ayat al-quraan juga menjelaskan tentang berakhlak baik kepada guru Sebagaimana ayat dibawah ini surah Al-kahfi ayat 66-70, berikut:

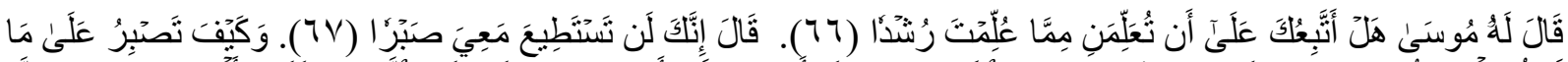

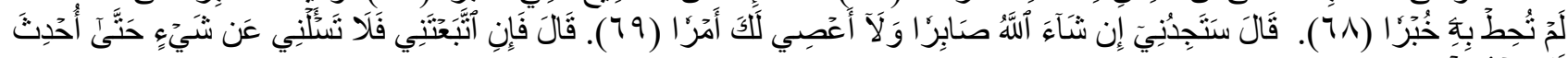

Artinya: Musa berkata kepada (Khidhr): "Bolehkah aku mengikutimu supaya kamu mengajarkan kepadaku ilmu yang benar di antara ilmu-ilmu yang telah diajarkan kepadamu? (66). Dia menjawab: "Sesungguhnya kamu sekali-kali tidak akan sanggup sabar bersama aku (67). Dan bagaimana kamu dapat sabar atas sesuatu, yang kamu belum mempunyai pengetahuan yang cukup tentang hal itu? (68). Musa berkata: "Insya Allah kamu akan mendapati aku sebagai orang yang sabar, dan aku tidak akan menentangmu dalam sesuatu urusanpun" (69). Dia berkata: "Jika kamu mengikutiku, maka janganlah kamu menanyakan kepadaku tentang sesuatu apapun, sampai aku sendiri menerangkannya kepadamu" (70). (QS. al-Kahfi [18]: 66-70).

Al-Qurtubi mengungkapkan tentang, ayat diatas mengutamakan 2 harapan, 1. pentingnya adab yg baik. 2. sebagai ajaran sebagai orang menuntut ilmu hendakl ah mengikuti atau memiliki pengajar (Tafsir al-Qurthubi, 1964: 11/ 17). sementara itu, berdasarkan Syekh al-Sya'rawi, ayat ini menunjukkan pada kita perihal adab nabi Musa saat ber-talaqqi, antara siswa pada guru. Padahal Allah yang memberi perintah untuk menuruti Hidhir, tapi Musa tidak langsung berkata "sesungguhnya saya diperintah Allah untuk mengikutimu", namun Musa mengatakannya dengan lembut "bolehkah saya mengikutimu..". (Tafsir al-Sya'rawi, 1997: 14/ 8955). Adab Musa terlihat jelas di surah al-Kahfi ayat 66-70. bahwa beliau meminta untuk mengiringi atau menjadi khadim Khidir, bukan langsung meminta supaya Khidhir mengajarnya. Maka sudah sangat jelas 
bahwa akhlak sangat lah penting bagi seseorang terutama pada gurunya, serta hadist dibawah ini juga mengungkapkan tetang penting nya dalam berakhlak.

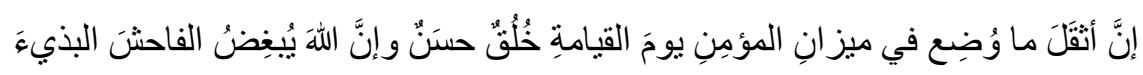

Artinya: Sesungguhnya perkara yang lebih berat di timbangan amal bagi seorang Mu'min adalah akhlak yang baik. Dan Allah tidak menyukai orang yang berbicara keji dan kotor (HR. At Tirmidzi no. 2002, ia berkata: "hasan shahih").

Dari beberapa aspek ruang lingkup pendidikan akhlak yang telah dikemuka kan diatas bisa kita taati dan jalankan dalam kehidupan sehari-hari karena berakhlak mulia adalah dasar yang berperan penting, landasan penting akhlak dalam Rasullullah Saw. bersabda dalam Hadisnya dijelaskan yang artinya: Abu Hurairah r.a mengatakan, bahwa Rasulullah Saw. bersabda "Sesungguhnya aku diutus hanyalah untuk menyempurnakan akhlak yang baik". (HR. Ahmad dan Baihaqi). Dari ayat Al-Qur'an dan Hadis Rasulullah Saw. di atas memperlihatkan bahwa landasan dan pijakan pendidikan akhlak adalah AlQur'an dan Hadis. Merupakan pedoman untuk bisa kita ketahui ciri-ciri suatu perbuatan itu baik maupun buruk.

Dengan begitu dalam artian bahwa Pendidikan akhlak yaitu tingkah laku atau kemauan manusia dengan niat yang damai dan jiwa yang berlandaskan Al-quraan dan AlHadis yang mendatangkan perbuatan-perbuatan atau kebiasaan-kebiasaand dengan mudah tanpa memerlukan pembimbing terlebih dahulu. Dengan begitu akhlak yang mulia merupakan norma-norma yang sudah ada didalam alqur'an sebagai aturan yang berlaku bagi bagi manusia di muka di dunia, dan pendekatan normatif ini bersumberkan Alqur'an serta hadis, bahwa norma-norma yang terdapat didalam al-qur'an dan hadist merupakan suatu ketetapan dan tidak bisa di campur tangan oleh manusia. Dan Allah tidak menyukai orang yang keji dan kotor. landasan ini lah ketaatan kepada perintah Allah sifatnya kondisional, jika objek dari aturan tersebut sesuai dengan ketentuan Allah dan Rasul-Nya, maka wajib diikuti, sedangkan jika hal tersebut bertentangan dengan kehendak Allah, maka tidak harus menigikutinya.

\section{METODE PENELITIAN}

Metode yang digunakan pada penelitian ini yaitu metode kualitaif deskriptif dapat berupa penyelidikan, pengamatan mendalam dan prosedur ilmiah untuk memeberikan kesimpulan dalam bentuk narasi yang mendukung berberapa analisis data. Metode dalam peneltian ini dapat berupa metode kepustakaan. Metode ini menggunakan bentuk penelitian yang berasal dari artikel ilmiah, dengan berbagai sumber dari internet atau literatur, dan lain sebagainya. Dalam penelitian ini, data diperoleh melalui teknik pengumpulan data kepustakaan dari artikel ilmiah. (Urip and Maemonah) Serta yang bersumber dari ayat-ayat al-Qur'an dan hadis yang memuat tentang akhlak siswa terhadap guru, buku-buku yang mengacu pada teori penelitian, serta beberapa penelitian sebelumnya yang terkait. Teknik pengumpulan data menggunakan teknik membaca serta mencatat. Teknik analisis data yaitu analisis isi dengan menggunakan pendekatan normatif terhadap teks yang terdapat pada ayat-ayat Alquran dan hadis.

\section{HASIL PENELITIAN DAN PEMBAHASAN}

Hasil dari penelitian ini menyebutkan bahwa Islam normatif merupakan mengumpulkan sumber-sumber hukum terdapat dalam Al-Qur'an serta Hadist atau Hadis Nabi yang kebenarannya bersifat mutlak yang murni dari firman Allah SWT. tanpa terdapat campur tangan manusia. menjadi contoh yaitu turunnya ayat Al-Quran yaitu aspek normatif islam yang memiliki kedudukan mutlak, sehingga kebenaran yang terdapat di dalam Al-Quraan artinya kebenaran yang sudan jelas serta sempurna. ('Adzim and Vrikati) 
Dengan begitu akhlak yang mulia artinya norma-norma yang sudah ada didalam alqur'an sebagai hukum yang berlaku bagi kita umat manusia di muka bumi ini, serta pendekatan normatif ini bersumberkan Al-qur'an serta hadis, bahwa norma-norma yang terkandung didalam al-qur'an serta hadist merupakan suatu ketetapan serta tidak mampu di campur tangan oleh manusia. serta allah tidak menyukai orang yang keji dan kotor. Atas dasar inilah ketaatan kepada perintah allah sifatnya kondisional, maka sudah kentara bahwa akhlak merupakan hal yang sangat penting untuk diterapkan semenjak dini, yang adalah norma-norma yang ada di dalam Al-Quraan dan hadis.

Tabel 1. Analisis jurnal tentang akhlak siswa berdasarkan al-quraan dan hadis

\begin{tabular}{|c|c|c|c|c|}
\hline No & Penulis, & Jurnal & Judul & $\begin{array}{c}\text { Sinta dan } \\
\text { Tahun }\end{array}$ \\
\hline 1. & $\begin{array}{l}\text { Abdul Jabar Idhaudin, } \\
\text { Akhmad Alim, \& Abdul } \\
\text { Hayyie Al Kattani }\end{array}$ & $\begin{array}{l}\text { Jurnal As- } \\
\text { Salam }\end{array}$ & $\begin{array}{l}\text { Penerapan } \\
\text { Pendidikan Akhlak Syaikh } \\
\text { Utsaimin di SDIT Al- } \\
\text { Hidayah Bogor }\end{array}$ & Sinta 5 (2019) \\
\hline 2. & Mudir & $\begin{array}{l}\text { Jurnal } \\
\text { Pendidikan } \\
\text { Islam } \\
\text { Indonesia }\end{array}$ & $\begin{array}{l}\text { Penerapan } \\
\text { Saintifik Dendekatan } \\
\text { Dalam Normatif } \\
\text { Aqidah Pembelajaran } \\
\text { Madrasah Ibtidaiyah }\end{array}$ & $\begin{array}{l}\text { Sinta } 4 \\
(2017)\end{array}$ \\
\hline 3. & Ani Nur Aeni & $\begin{array}{l}\text { Mimbar } \\
\text { Sekolah Dasar }\end{array}$ & $\begin{array}{l}\text { Pendidikan Karakter } \\
\text { Untuk Siswa SD Dalam } \\
\text { Perspektif Islam }\end{array}$ & Sinta $3(2014$ \\
\hline 4. & Ibrahim Bafadhol & $\begin{array}{l}\text { jurnal } \\
\text { pendidikan } \\
\text { islam }\end{array}$ & $\begin{array}{l}\text { Pendidikan Akhlak Dalam } \\
\text { Perspektif Islam Edukasi } \\
\text { Islami }\end{array}$ & $\begin{array}{l}\text { Sinta } 2 \\
(2016)\end{array}$ \\
\hline
\end{tabular}

Berdasarkan dari beberapa uraian analisis artikel jurnal terdahulu yang peneliti kutip dari sinta 2-5 sebanyak 4 artikel memuat tentang akhlak siswa kepada guru berdasarkan al-quraan dan hadis, dari uraian tersebut menjelaskan bahwa dalam pembentukaan akhlak siswa tidak hanya dilingkungan sekolah saja namun juga perlu dibiasakan dalam lingkungan keluarga, sebuah pembiasaan berakhlak yang baik sopan santun baik dalam bertutur kata dilakukan sejak usia dini, maka hal tersebut akan membentuk akhlak seorang anak yang baik, sebagai seorang guru kita bisa mengajarkan serta menerapkan akhlak yang baik salah satu contohnya ketika di sekolah hendaklah berbicara sopan kepada guru, saling menghormati sesama teman, dan lingkungan sekitarnya.

Pada pembiasaan akhlak yang baik, memiliki beberapa ruang lingkup yaitu pertama Akhlaq kepada Allah SWT, disini kita sebagai hamba nya berkewajiban agar mempunyai akhlak mulia pada Allah Swt. Melalui cara menjaga keinginan taat dalam beribadah, serta taat berdasarkan tauhid, taat terhadap perintah Allah Swt serta menjauhkan diri dari larangan dengan ikhlas beramal sholeh.

Selanjutnya akhlak terhadap diri sendiri, maksudnya adalah seseorang yang telah diciptakan dalam keimanan kepada Allah SWT. Dalam kemampuan fitrah manusia diberikan kewajiban menjaga serta menjaga kesucian lahir maupun batin. Yang ketiga yaitu akhlak kepada keluarga bisa dilaksanakan dengan cara berbakti kepada orang tua, bergaul dengan baik, memberi nafkah sebaik mungkin. Yang keempat akhlak kepada tetangga Membina tetangga sangat penting, karena tetangga adalah sahabat yang terdekat, Bahkan nabi Muhammad bersabda artinya:

" Tidak henti-hentinya jibril menyuruhku untuk berbuat baik kepada tetangga, hingga aku merasa tetangga sudah seperti ahli waris” (HR Bukhori)

Yang kelima yaitu akhlak terhadap pemimpin sebagai manusia meski siap menjadi pemimpin maupun dipimpin jika menjadi seorang pemimpin maka akan diberikan kewajiban agar mempunyai 
akhlak yang baik karena akan menjadi contoh yang baik bagi banyak orang, dan jika kita menjadi orang yang dipimpin maka kita meski patuh serta taat kepada pemimpin kita selama yang memimpin tidak beberperilaku dzolim.

Keenam yaitu akhlak kepada lingkungan Akhlak kepada lingkungan, Lingkungan merupakan semua hal yang ada didekat kita sebagai manusia seperti hewan, tumbuh-tumbuhan serta benda mati. Akhlak yang dikembangkan merupakan contoh dari tugas kita sebagai manusia pemimpin di muka bumi ini yaitu agar menjaga agar setiap proses pertumbuhan alam dapat terus berjalan berdasarkan fungsi ciptaan-Nya,

Akhlak kepada lingkungan juga menjelaskan tentang bagaimana seorang siswa berakhlak kepada guru, dijelaskan pada ayat Al-Quraan (QS. al-Kahfi [18]: 66-70). Merupakan dalil bahwa seorang yang belajar mencari ilmu hendaklah mengikuti atau memiliki guru.

\section{KESIMPULAN}

Dengan pendekatan normatif inilah permasalahan tentang pendidikan serta akhlak peserta didik dalam lingkungan masyarakat sekolah maupun keluarga memang perlu ditegaskan dengan ayat-ayat Al-Qu'an dan Sunnah Rasul tanpa menggunakan pemikiran-pemikiran dan logika manusia yang masih saja menganggap akhlak itu hal yang biasa sementara di dalam alquran sudah sudah tertulis jelas bahwa adab terhadap guru itu penting dan merupakan perbuatan yang mulia. Salah satunya terdapat pada QS. al-Kahfi ayat 66-70 penting nya beradab baik. yang kedua, sebagai dalil jika seorang yang mencari ilmu meski menuruti dan memiliki seorang pengajar. dan ayat tersebut menjelaskan pada kita tentang tentang adab nabi Musa ketika ber-talaqqi, antara murid kepada gurunya.

Untuk memperbaki akhlak siswa terhadap guru maupun orangtua serta lingkungannya, maka penerapan pendekatan normatif di dalam Al-Qur'an maupun Hadis perlu diterapkan sejak dini, perlu ditegaskan dengan ayat-ayat Al-Quraan dan Sunnah Rasul tanpa menggunakan pemikiranpemikiran dan logika manusia. Sebagaimana penelitian yang sudah dilakukan pada analisis jurnal tentang akhlak bersumberkan Al-Qur'an dan Hadis.

\section{DAFTAR PUSTAKA}

'Adzim, Muhammad Fauzil, and Nela Syarah Vrikati. "Studi Islam Dalam Kaca Mata Normatif Dan Historis." Al-Munqidz: Jurnal Kajian Keislaman, vol. 8, no. 3, 2020, pp. 441-52, doi:10.52802/amk.v8i3.275.

Ahmad, AFghor Fahruddin, Syamsi Moh. "Korelasi Antara Strategi Nilai-Nilai Pendidikan Karakter Religius Dengan Terbentuknya Akhlaq Dalam Diri Siswa.” Attaqwa: Jurnal Ilmu Pendidikan Islam, vol. 16, no. 2, 2020, pp. 141-50.

Ani, Nur Aeni. "Pendidikan Karakter Untuk Siswa SD Dalam Perspektif Islam.” Mimbar Sekolah Dasar, vol. 1, no. 1, 2014, pp. 50-58.

Bafadhol, Ibrahim. "Pendidikan Akhlak Dalam Persfektif Islam." Jurnal Edukasi Islami Jurnal Pendidikan Islam, vol. 06, no. 12, 2017, pp. 45-61.

Bermi, Wibawati. "Internalisasi Nilai-Nilai Agama Islam Untuk Membentuk Sikap Dan Perilaku Siswa Sekolah Dasar Islam Terpadu Al-Mukminun 1 Ngrambe Ngawi.” Jurnal Al Lubab, vol. 1, no. 1, 2016, pp. 1-18.

Firdaus. "Membentuk Pribadi Berakhlakul Karimah.” Al - Dzikra, vol. XI, no. 1, 2017, pp. 55-88, https://media.neliti.com/media/publications/178009-ID-membentuk-pribadi-berakhlakulkarimah-se.pdf.

Gustini, Neng. "Bimbingan Dan Konseling Melalui Pengembangan Akhlak Mulia Siswa Berbasis Pemikiran Al-Ghazali." Tadris: Jurnal Keguruan Dan Ilmu Tarbiyah, vol. 1, no. 1, 2016, pp. 1-14, www.unissula.ac.id.

Idhaudin, Abdul Jabar, et al. "Penerapan Model Pendidikan Akhlak Syaikh Utsaimin Di Sdit Al- 
Hidayah Bogor." Jurnal As-Salam, vol. 3, no. 3, 2019, pp. 53-66, doi:10.37249/assalam.v3i3.137.

Mudir. "Penerapan Pendekatan Saintifik." Jurnal Pendidikan Islam Indoneia, vol. 1, no. 2, 2017.

Nur, M. "Keniscayaan Pendekatan 'Pluralistik - Idealistik' Dalam Pengkajian Islam.” IN RIGHT Jurnal Agama Dan Hak Azazi Manusia, vol. 3, no. 1, 2013, pp. 1-41.

Salsabila, Krida, and Anis Husni Firdaus. "Pendidikan Akhlak Menurut Syekh Kholil Bangkalan." Jurnal Penelitian Pendidikan Islam, vol. 6, no. 1, 2018, p. 39, doi:10.36667/jppi.v6i1.153.

Shaifudin, Arif. "Memaknai Islam Dengan Pendekatan Normatif." El-Wasathiya: Jurnal Studi Agama, vol. 5, no. 1, 2017, pp. http://ejournal.kopertais4.or.id/mataraman/index.php/washatiya/article/view/3023.

Urip, Kurniawati Meilina, and Maemonah. "Analisis Hierarki Kebutuhan Maslow Dalam Pembelajaran Daring Anak Usia Dasar: Analisis Jurnal Sinta 2 Sampai 6." AULADUNA: Jurnal Pendidikan Dasar Islam, vol. 8, no. 1, 2021, p. 51, doi:10.24252/auladuna.v8i1a5.2021. 